\title{
Effects of turbulence on TEP dynamics under contrasting nutrient conditions: implications for aggregation and sedimentation processes
}

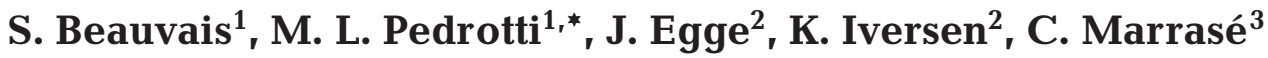 \\ ${ }^{1}$ Marine Microbial Ecology Group, Laboratoire d'Océanographie de Villefranche, Univ. Paris VI, CNRS UMR 7093, \\ Observatoire Océanologique de Villefranche-sur-Mer, Station Zoologique, BP 28, 06234 Villefranche-sur-Mer, France \\ ${ }^{2}$ Department of Fisheries and Marine Biology, University of Bergen, HIB, 5020 Bergen, Norway \\ ${ }^{3}$ Departament de Biologia Marina i Oceanografia, Institut de Ciències del Mar, (CSIC) Passeig Maritim de la Barceloneta, \\ Barcelona, Spain
}

\begin{abstract}
The effect of different small-scale turbulence intensities on transparent exopolymeric particle (TEP) dynamics was studied in natural North Sea coastal waters. The abundance, volume, size spectra and carbon content of TEP were examined in mesocosms with and without added nutrients: no addition (T series) and a Redfield ratio supply on Day 1 (NT series), fertilized with $16 \mu \mathrm{M}$ N:1 $\mu \mathrm{M}$ P:32 $\mu \mathrm{M}$ Si to favor phytoplankton production in the form of a bloom. Turbulence was generated by vertically oscillating grids, operating continuously for $14 \mathrm{~d}$. We determined whether TEP production, under contrasting nutrient conditions, changes with level of turbulence. TEP concentration increased with turbulence. The effect of turbulence was likely indirect, by inducing an increase in growth rates of diatoms that actively exude TEP precursor, particularly when nutrients were exhausted. Following TEP production, the ratio of particulate organic carbon to nitrogen increased after the bloom, regardless of turbulence level. TEP formation led to a decoupling of carbon and nitrogen dynamics, with a large flow of carbon channeled into the TEP pool, representing up to $44 \%$ of the primary production, and was constant with the turbulence intensity. While turbulence had no effect on small particles $(<40 \mu \mathrm{m})$, turbulence favored the aggregation of TEP $>40 \mu \mathrm{m}$. We found significant sedimentation of TEP when turbulence was lower $\left(5\right.$ to $\left.8 \times 10^{-2} \mathrm{~cm}^{2} \mathrm{~s}^{-3}\right)$ and a persistence of the TEP pool in the tanks without sinking at higher levels of turbulence intensity, typical of storm events $\left(\varepsilon=1 \mathrm{~cm}^{2} \mathrm{~s}^{-3}\right)$.
\end{abstract}

KEY WORDS: Transparent exopolymer particles - TEP production - Phytoplankton · POC · Turbulence $\cdot$ Nutrients $\cdot$ Aggregation $\cdot$ Mesocosms

Resale or republication not permitted without written consent of the publisher

\section{INTRODUCTION}

The role of organic aggregates in marine food webs and vertical transport process is now well recognized (Dam \& Drapeau 1995, Passow 2002b, Simon et al. 2002). Aggregation is primarily controlled by: (1) particle characteristics (concentration, density, size distribution and shape), (2) physical processes (shear and differential settling velocities) and (3) the probability of particles sticking together after collision (McCave
1984, Dam \& Drapeau 1995, Kiørboe 1997, Li \& Logan 1997). Because of their chemical nature, high abundance, large size and high 'stickiness', transparent exopolymeric particles (TEP) represent a key component of the aggregation process in the pelagic system (Jackson 1995, Passow \& Alldredge 1995, Mari \& Burd 1998, Prieto et al. 2002). These particles are generated abiotically from polysaccharide precursors released from phytoplankton and bacteria as dissolved and colloidal matter (Zhou et al. 1998, Passow 2000a). TEP 
formation is an important pathway in the conversion of dissolved to particulate organic carbon, enhancing the aggregation and sedimentation of particles to form marine snow, especially during phytoplankton blooms (Alldredge et al. 1993, Logan et al. 1995, Engel et al. 2004). Because of their high carbon content, TEP contribute to the carbon export from the surface of the ocean (Passow et al. 2001, Beauvais et al. 2003).

Turbulence and the shear associated with it are known to influence the structure of the pelagic trophic web (Margalef 1978, Peters \& Marrasé 2000, Maar et al. 2002). The mechanical energy of waves, currents and tides generates eddy motions that are transferred to ever-smaller eddy scales, due to the cascading nature of turbulence, where molecular effects start to dominate. Small-scale turbulence describes a flow phenomenon on a 3-dimensional scale ranging from meters down to millimeters, until viscosity forces compensate inertial forces. In the present paper, we use the term 'turbulence' in a broad sense, including motions below the microscale. To date most studies have focused on the role of turbulence on biological processes, such as planktonic production and respiration (Alcaraz et al. 2002), zooplankton feeding (e.g. Caparroy et al. 1998), microzooplankton feeding (Dolan et al. 2003, Havskum et al. 2005), osmotrophic plankton (Arin et al. 2002) and bacterial growth (Peters et al. 1998, Maltis et al. 2004). All these processes affect the dynamics of the particles suspended within, and exported from, the water column, but their net effect on production of non-living particulate matter is difficult to predict. The possible effect of turbulence on a particular class of particles, such as TEP, is even more obscure. Overall, little is known concerning the effect of small-scale turbulence on TEP formation and aggregation and their significance to biogeochemical processes. The only exception we are aware of are the conclusions of Stoderegger \& Herndl (1999) that colloids released by bacteria coagulate under a turbulence effect to form TEP.

In the natural environment, peak concentrations of TEP are usually associated with phytoplankton blooms, especially blooms dominated by diatoms (Passow \& Alldredge 1994, 1995, Mari \& Kiørboe 1996, Grossart \& Simon 1997, Passow et al. 2001). We suggest that turbulence could promote TEP production by enhancing the activity of the primary biological source of TEP. In turn, TEP dynamics may influence the stoichiometry of the system. For example, exopolymer production by phytoplankton increases during nutrient-limiting conditions (Myklestad \& Haug 1972). In the NW Mediterranean Sea, during a nitrate-limiting period, TEP are abundantly produced, leading to the formation of a large pool of particulate organic carbon, with a high carbon:nitrogen ratio (Mari et al. 2001,
Beauvais et al. 2003). Since TEP originate from these exopolymers, turbulence may affect the stoichiometry of carbon and nitrogen into the system by modifying TEP dynamics.

The objectives of the present study were: (1) to investigate whether the production of TEP, under contrasting nutrient conditions, changes with the level of turbulence and what this implies for aggregation and sedimentation processes and (2) to determine the effect of the TEP pool on the carbon dynamics, under contrasting turbulence regimes.

\section{MATERIALS AND METHODS}

Experimental set-up and enclosure treatments. The 2 wk experiment was carried out in July 2001 at the Marine Biological Field Station (Raunefjord, Norway; $60^{\circ} 16^{\prime} \mathrm{N}, 5^{\circ} 14^{\prime} \mathrm{E}$ ) in the framework of the European NTAP (Nutrient dynamics mediated through Turbulence And Plankton interactions) program. The experimental set-up consisted of six $2.6 \mathrm{~m}^{3}$ on-land cylindrical polyethylene tanks (1.5 m inner diameter, $1.5 \mathrm{~m}$ depth) with $90 \%$ PAR (photosynthetically active radiation) transmission. These mesocosms were filled simultaneously with nutrient-depleted, post-bloom water by pumping it out of the fjord from $5 \mathrm{~m}$ depth. The subsurface water was screened through a $250 \mu \mathrm{m}$ mesh nylon netting to remove mesozooplankton. Experimental tanks were inside larger enclosures filled with circulating seawater to maintain approximate in situ temperature. The experimental tanks were exposed to 3 different turbulence intensities maintained continuously (except during sampling) over the $14 \mathrm{~d}$ duration of the study. The tanks were divided into 2 treatment series: no addition of nutrients ( $\mathrm{T}$ tanks) and those supplied with nutrients in a Redfield ratio on Day 1 (NT tanks). NT tanks were fertilized with nutrients (16 $\mu \mathrm{M}$ N:1 $\mu \mathrm{M}$ $\mathrm{P}: 32 \mu \mathrm{M} \mathrm{Si}$ ) to favor bloom development. An overview of treatments for each tank is summarized in Table 1.

Table 1. Experimental set-up and terminology. Experimental tanks were divided into 2 treatment series: no addition of nutrients ( $\mathrm{T}$ tanks) and a Redfield ratio supply on Day 1 $(16 \mu \mathrm{M} N: 1 \mu \mathrm{M}$ P:32 $\mu \mathrm{M}$ Si) (NT tanks). Turbulence levels are given as mean energy dissipation rates $(\varepsilon)$ calculated from energy spectra using a linear regression method (Stiansen \& Sundby 2001)

\begin{tabular}{|lcc|}
\hline$\varepsilon\left(\mathrm{cm}^{2} \mathrm{~s}^{-3}\right)$ & T tanks & NT tanks \\
\hline $2 \times 10^{-5}$ (still water $)$ & T0 & NT0 \\
5 to $8 \times 10^{-2}$ & T2 & NT2 \\
1 & T4 & NT4 \\
\hline
\end{tabular}


Turbulence was generated using vertically oscillating grids placed at a depth of $1 \mathrm{~m}$ and with a vertical stroke of $40 \mathrm{~cm}$. This system is, in our view, the best generator of turbulence for large container experiments, because it creates nearly homogeneous conditions. However, as in all systems, some inconsistencies are involved in the temporal and spatial distribution of turbulence (Nerheim et al. 2002). The grids consisted of a steel skeleton covered with Teflon and 2 Plexiglas grids (10 cm opening, $5 \mathrm{~cm}$ grid width) attached to it. By regulating the vertical movement of the grid (speed, frequency and stroke), 2 turbulence levels ( T2 $=5$ to $8 \times 10^{-2}$ and $\mathrm{T} 4=1 \mathrm{~cm}^{2} \mathrm{~s}^{-3}$ ) were generated, as indicated in Table 1 . Two mesocosms were not influenced by artificial turbulence (T0 and NT0). The values are in the range of turbulence intensities found in oceans (MacKenzie \& Legget 1993, Simpson et al. 1996). An acoustic Doppler flow meter was used to measure water velocity and turbulent kinetic energy. Dissipation rates $\left(\mathrm{cm}^{2} \mathrm{~s}^{-3}\right)$ were calculated from energy spectra using a linear regression method (Stiansen \& Sundby 2001). According to these authors, the energy dissipation rate $(\varepsilon)$ is the best measure of turbulence intensity in small-scale turbulence experiments. We used 2 grids in each tank to cover as much vertical distance as possible and thus minimize heterogeneity. From the organism's perspective, turbulence is strong as the grid moves by. In natural conditions turbulence is not constant either. However, the $-5 / 3$ slopes of the spectral density found and the bulk homogeneity in turbulent kinetic $\varepsilon$ suggest that turbulence is nearly isotropic.

Sampling procedure. Integrated samples were taken daily, or every other day, from each mesocosm using Plexiglas tubes with a volume of 31 (5 cm diameter), at 09:00 h, from Days 0 to 14 . Subsamples were collected for the determination of suspended chlorophyll a (chl a), primary production (PP), particulate organic carbon (POC) and nitrogen (PON), nutrients and TEP. Nutrient concentrations were analyzed every second day. Analyses of silicate and phosphate were conducted on freshly collected samples based on the methods described in Valderrama (1995) and Koroleff (1983), respectively. A Shimadzu UV-160 spectrophotometer was used for reading the samples. Nitrate and nitrite were analyzed on a Skalar autoanalyzer immediately after the experiment on samples preserved with chloroform. The chl a concentration was analyzed fluorimetrically in $90 \%$ acetone extracts (Parsons et al. 1984). Chl a was converted into C (C-phyto) using a C:chl ratio (wt:wt) of 50 (Arin et al. 2002). PP was measured using the ${ }^{14} \mathrm{C}$ method, according to Steeman-Nielsen (1952) and Gargas (1975). Plastic bottles (76 ml, NUNC Easyflask), inoculated with approximately $4 \mu \mathrm{Ci}$, were incubated in situ in the mesocosms for approximately 150 min between 11:00 and 14:00 h. After incubation, samples were filtered onto Satorius membrane filters $(0.45 \mu \mathrm{m})$ and frozen $\left(-20^{\circ} \mathrm{C}\right)$. The samples were later counted in a Packard Tri Carb liquid scintillation analyzer (Model 1900A) after fuming with $\mathrm{HCl}$. POC and PON concentrations were measured from samples of increasing volume $(100,300$ and $500 \mathrm{ml})$ filtered onto precombusted Whatman GF/F glass-fiber filters and analyzed using a Leco $900^{\mathrm{TM}} \mathrm{CHN}$ analyzer.

TEP determination, size spectra and carbon content. Water samples for TEP analysis were collected every second day. Samples were prepared fresh, within $2 \mathrm{~h}$ following collection. Several seawater aliquots $(3,5$ and $10 \mathrm{ml}$ ) were gently filtered through $0.2 \mu \mathrm{m}$ white Nuclepore $^{\mathrm{TM}}$ filters under constant and low pressure. Materials retained on the filter were stained with $500 \mu \mathrm{l}$ of an aqueous solution of $0.06 \%$ acetic acid ( $\mathrm{pH} 2.5$ ) and $0.02 \%$ Alcian blue 8GX. After the staining procedure, filters were mounted directly on a white slide (Cyto-Clear®). This technique provides direct observations of TEP on the filter (Logan et al. 1994). Then, TEP were observed through an Axiophot-Zeiss microscope. Pictures were captured with a CCD color video camera (COHU 2252$1040,752 \times 582$ pixel resolution, 0.08 lux minimum sensitivity). TEP were counted using Image Pro Plus 4 software. A minimum of 600 TEP were counted and sized at 3 successive magnifications $(100 \times, 200 \times, 400 \times)$ in order to better cover the entire size spectrum (Mari \& Burd 1998). The equivalent spherical diameter (ESD) of each TEP was calculated from the measurement of crosssectional area using a semi-automatic image-analysis system. Counts were binned by ESD into 15 logarithmic size classes between 1 and $135 \mu \mathrm{m}$.

The TEP size distribution follows a classical powerlaw function, which is defined by the equation from McCave (1984):

$$
\mathrm{d} N / \mathrm{d}\left(d_{\mathrm{p}}\right)=\mathrm{k} d_{\mathrm{p}}^{\delta}
$$

where $d N$ is the number of particles per unit volume with a diameter ranging from $d_{\mathrm{p}}$ to $\left[d_{\mathrm{p}}+\mathrm{d}\left(d_{\mathrm{p}}\right)\right]$, where $d_{\mathrm{p}}$ is the projected spherical encased diameter. The constant $\mathrm{k}$ depends on particle concentration and the slope $\delta$ relates the abundance of small to large particles. Linear regressions of $\log \left[\mathrm{d} N / \mathrm{d}\left(d_{\mathrm{p}}\right)\right]$ vs. $\log \left[d_{\mathrm{p}}\right]$ were used to calculate $\mathrm{k}$ and $\delta$. Slopes of regression lines were statistically compared using analysis of covariance (ANCOVA) performed using SYSTAT software. Data characteristics (normality of residuals, homoscedasticity and linearity) were also tested to ensure conformity with assumptions of parametric statistics, and logarithmic transformations were required. The number of TEP $\mathrm{ml}^{-1}$ was normalized by the size of the size class $(\mu \mathrm{m})$ considered. TEP volume concentrations are given in ppm. 


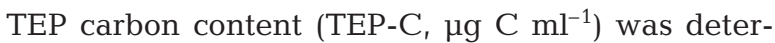
mined from the size-frequency distribution using the size-dependent relationship proposed by Mari (1999):

$$
\text { TEP-C }=0.25 \Sigma_{i} n_{i} r_{i}^{2.55}
$$

where $n_{i}$ is the concentration of particles in Size Class $i$ and $r_{i}$ is the TEP radius $(\mu \mathrm{m})$ in the same size class.

After Day 14, we performed a resuspension assay by gently mixing mesocosm water followed by a final sampling. Enrichment factors (EF), i.e. materials (TEP and chl a concentrations) found after resuspension compared to those found before resuspension, illustrate the loss of materials due to sedimentation. EF values equal to 1 mean that no sedimentation occurred.

\section{RESULTS}

\section{Nutrients and phytoplanktonic biomass}

Initial nitrate concentrations in enclosures filled with natural seawater were $0.67 \pm 0.19 \mu \mathrm{M}$, phosphate concentrations were $0.24 \pm 0.04 \mu \mathrm{M}$, and silicate concentrations were $1.50 \pm 0.06 \mu \mathrm{M}$. The nutrient molar ratio $\left.\left(\left[\mathrm{NO}_{3}\right]+\left[\mathrm{NO}_{2}\right]+\left[\mathrm{NH}_{4}\right]\right):\left[\mathrm{PO}_{4}\right]\right)$ was 4.65 . The low concentration of $\mathrm{NO}_{3}$ and $\mathrm{PO}_{4}$ indicated that the initial water was from a nutrient-depleted, post-bloom period. The chl a concentration was $1.40 \pm 0.30 \mu \mathrm{g} \mathrm{l}^{-1}$. The phytoplanktonic community was dominated by typical summer diatom species, including Chaetoceros sp.,
Without nutrient addition ( $\mathrm{T}$ )

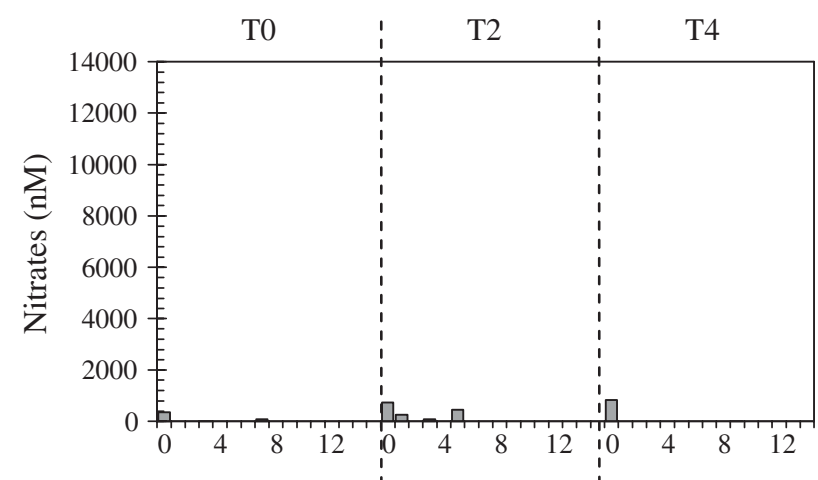

With nutrient addition (NT)

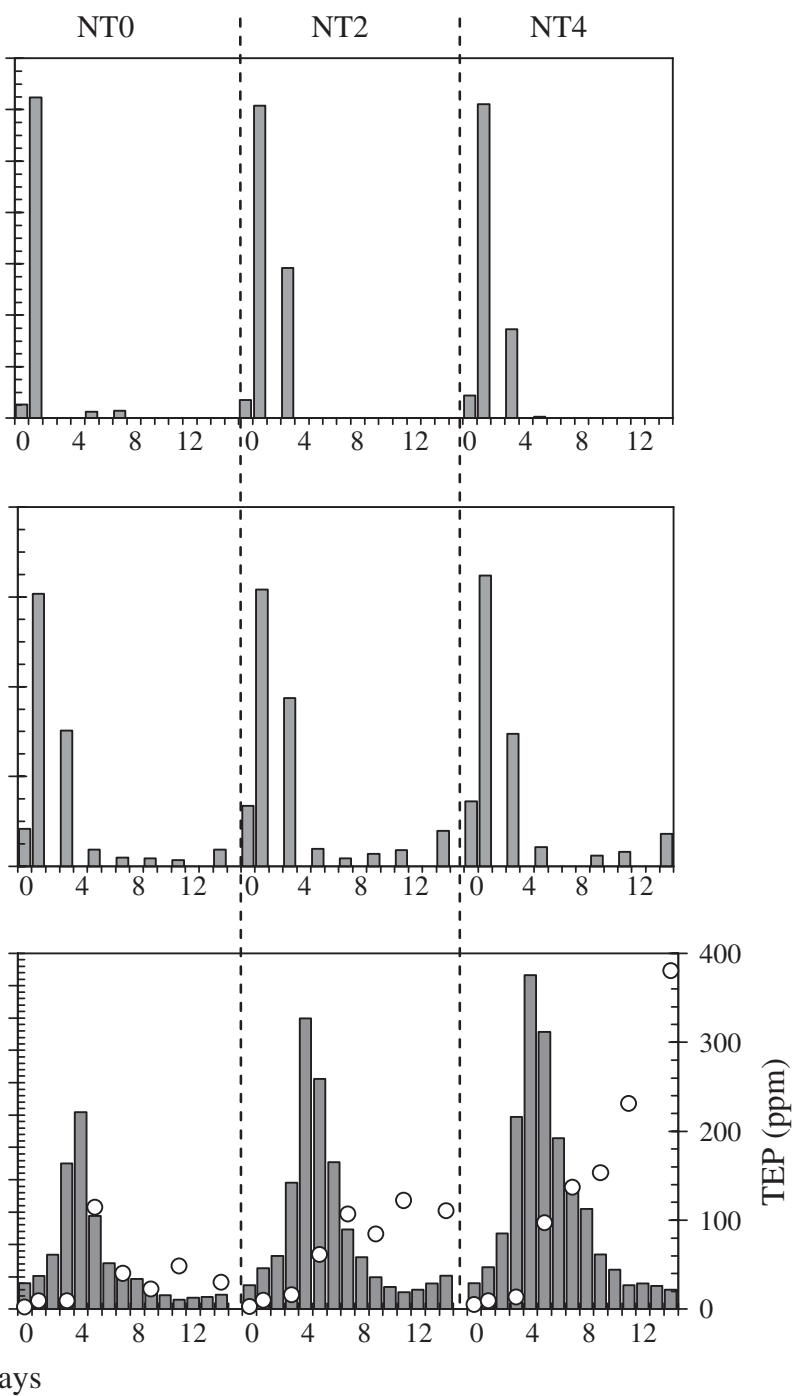

Fig. 1. Temporal evolution of nitrate, phosphate, chlorophyll a and transparent exopolymeric particle (TEP) concentrations in non-enriched (T) and enriched tanks (NT) from Days 0 to 14 of the experiments (O: TEP concentrations) 
Cylindrotheca closterium, Dactyliosolen fragilissimus and Nitzschia longissima (A. Jacobsen pers. comm.).

In non-enriched mesocosms ( $\mathrm{T}$ tanks), nitrates were rapidly consumed; after Day 1 the concentration was under the detection limit (Fig. 1). Phosphate dropped from an initial concentration of 0.24 to $0.12 \mu \mathrm{M}$ at the end of the experiment. Chl a concentration remained below $\sim 1.74 \mathrm{\mu g} \mathrm{l}^{-1}$ during the whole experiment, and Chaetoceros danicus was the dominant species. This diatom develops in natural seawater when nutrient concentrations are low.

In enriched mesocosms (Fig. 1; NT tanks), nitrate and phosphate concentrations were $12.28 \pm 0.18$ and $1.25 \pm$ $0.04 \mu \mathrm{M}$, respectively, on Day 1 , with a ratio of 9.9 $\left.\left(\left[\mathrm{NO}_{3}\right]+\left[\mathrm{NO}_{2}\right]+\left[\mathrm{NH}_{4}\right]\right):\left[\mathrm{PO}_{4}\right]\right)$. The nitrate concentration dropped below the detection limit after Day 3 in non-turbulent tanks, while in tanks with turbulence it took $5 \mathrm{~d}$. After phosphate addition, the concentration decreased within $3 \mathrm{~d}$ and remained relatively low in all tanks. Concurrently with the decline of nutrients, an increase of phytoplanktonic biomass occurred on Day 4 of the experiment in all enriched mesocosms. The phytoplankton bloom was due mainly to Skeletonema costatum and Thalassiosira sp. (A. Jacobsen pers. comm.). While there was no significant difference in chl a concentration between the 2 levels of turbulence during the experiment, chl a was significantly higher in turbulent tanks than in tanks without turbulence (Wilcoxon test, $\mathrm{n}=30, \mathrm{p}<0.01$ ) both during and after the bloom. Chlorophyll concentration increased with turbulence, with maximal concentrations of 12.2, 18.0 and $20.7 \mu \mathrm{g}$ chl $\mathrm{l}^{-1}$ in NT0, NT2 and NT4, respectively.

\section{TEP production}

Overall, TEP concentrations (ppm) were significantly lower in T tanks compared to NT tanks (Fig. 1). Temporal patterns differed with both nutrient conditions and turbulence. In T tanks with turbulence, TEP concentrations increased with time, from 2.9 (on Day 0) to $9.4 \mathrm{ppm}$ (on Day 14), from 3.8 to $10.3 \mathrm{ppm}$ and from 2.4 to $24.2 \mathrm{ppm}$, in T0, T2 and T4, respectively. In the T tanks with turbulence, the TEP volume was higher with higher turbulence: it increased 10-fold in $14 \mathrm{~d}$ in T4, while it increased only 3 -fold in $\mathrm{T} 0$ and $\mathrm{T} 2$.

In NT tanks, TEP dynamics were highly marked. Before the bloom (Day 4), TEP volume concentrations were similar to those found in $\mathrm{T}$ tanks. After Day 4, TEP concentrations increased sharply, from about 13 (on Day 3) to $91 \mathrm{ppm}$ (on Day 5) regardless of the turbulence intensity. As in $\mathrm{T}$ tanks, values were higher with higher turbulence. In NT4, TEP volume increased continuously until the end of the experiment, reaching 380 ppm on Day 14, i.e. 75 times higher than the initial conditions. Without turbulence, but with nutrients (NT0), maxima occurred just after the bloom (114.2 ppm). Afterward, TEP concentrations decreased, but remained relatively high (between 22.2 and $48.2 \mathrm{ppm}$ ). In NT2, TEP concentrations increased from the bloom until the senescent phase, reaching a stagnant phase between Days 7 and 14. During the last week, the TEP concentration was $106 \pm 16$ ppm in NT2.

Globally, TEP concentrations were higher in NT tanks and increased with turbulence level as chl a concentrations increased. The net apparent growth rates $\left(\mu \mathrm{d}^{-1}\right)$ of chl $a$ and TEP were closely linked, particularly in NT tanks (Fig. 2). These results indicate that the primary source of TEP in tanks was phytoplankton cells, in particular diatoms. TEP growth rates were, on average, $0.13 \pm 0.05$ and $0.57 \pm 0.06 \mathrm{~d}^{-1}$ in T and NT tanks, respectively. The negative growth rates for phytoplankton in $\mathrm{T}$ tanks indicated that no bloom had occurred.

\section{TEP size distribution}

For particles $<40 \mu \mathrm{m}$, we tested for a combined effect of turbulence and nutrients on the size distribution of TEP. ANCOVA results for the size spectrum as a function of turbulence intensity indicated insignificant covariance $(p=0.16 ; d f=2 / 224)$. The size distribution of TEP was thus not influenced by turbulence intensity, so data were pooled. Further analyses showed that nutrient conditions significantly affected the size distribution of TEP ranging from 2 to $40 \mu \mathrm{m}$ (Fig. 3 ; p < $0.005, \mathrm{df}=1 / 225$ ). In NT tanks, TEP were significantly more abundant in each size class, and regression slopes indicated that TEP were relatively larger in NT tanks (slope $=-2.5 \pm 0.05$ in $\mathrm{T}$ tanks and $-2.3 \pm 0.04$ in NT tanks). While turbulence had no effect on TEP $<40 \mu \mathrm{m}$, it seems that turbulence influenced the formation of larger TEP (Fig. 4). Indeed, in T and in NT tanks, the contribution of larger TEP $(>40 \mu \mathrm{m})$ was higher in turbulent mesocosms than in still ones. Ini-

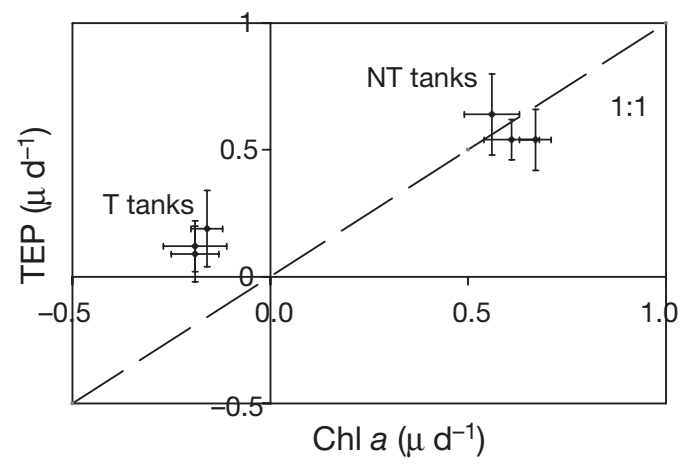

Fig. 2. Inter-comparison of TEP and chlorophyll a net growth rates $\left(\mu, \mathrm{d}^{-1}\right)$ during the exponential phase in tanks. Chlorophyll a decreased in T tanks, leading to negative $\mu$-values 


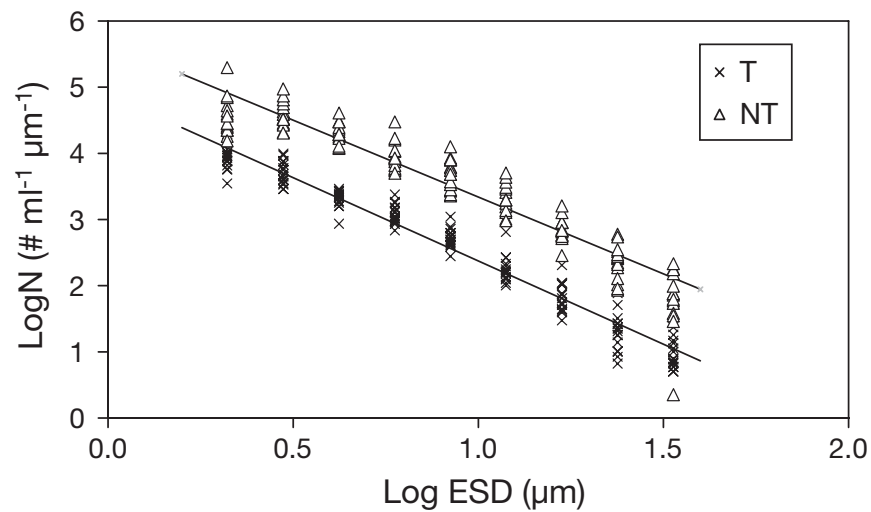

Fig. 3. TEP size spectrum with log-log transformation, in T and NT tanks for TEP from 1 to $40 \mu \mathrm{m}$. Regression lines $\left(\mathrm{d} N / \mathrm{d}\left[d_{\mathrm{p}}\right]=\mathrm{k} d_{\mathrm{p}}{ }^{\partial}\right)$ have been fitted to the data. Regression slopes $(\partial)$ are $-2.52 \pm 0.05$ for T and $-2.33 \pm 0.04$ for NT tanks.

ESD: equivalent spherical diameter

tially, on Day 1, large TEP represented between 21 and $29 \%$ of total TEP in all treatments; after the bloom, while large TEP contribution decreased in NT0, it increased in NT2 and NT4, reaching 33 and 48\%, respectively, after $14 \mathrm{~d}$ (Fig. $4 \mathrm{~b}$ ). In $\mathrm{T}$ tanks, even if the trend is less obvious, larger TEP were also less abundant without turbulence (Fig. 4a).

The resuspension assay showed that sedimentation was higher in NT tanks than in T tanks, where sedimented material was less abundant. Phytoplankton sinking was higher without turbulence, but it did not sink significantly (Table 2). Surprisingly, TEP sedimentation was higher with turbulence. In NT2, a >4-fold TEP concentration was found after resuspension.

\section{$\mathrm{C}$ and $\mathbf{N}$ temporal dynamics}

In nutrient-enriched mesocosms, POC and PON were tightly correlated during the exponential growth period of phytoplankton (Fig. $5 \mathrm{a} ; \mathrm{R}^{2}=0.99 ; \mathrm{n}=8$, p < $0.001)$. The POC:PON ratio was 6.3 , very close to the Redfield ratio. When nitrate was exhausted, from Day 5, the POC and PON dynamics became decoupled. The PON concentration increased slowly, while the POC concentration more than doubled, leading to a significant increase in the $\mathrm{C}: \mathrm{N}$ ratio of particulate organic matter (POM). The molar [POC]: $[\mathrm{PON}]$ ratios reached $11.4 \pm 0.3,12.4 \pm$ 0.9 and $16.3 \pm 0.5$ in NT0, NT2 and NT4, respectively (Fig. 5b). In all treatments, the TEP carbon content and POM C:N ratio were positively correlated, particularly in the enriched mesocosms, where the relationships

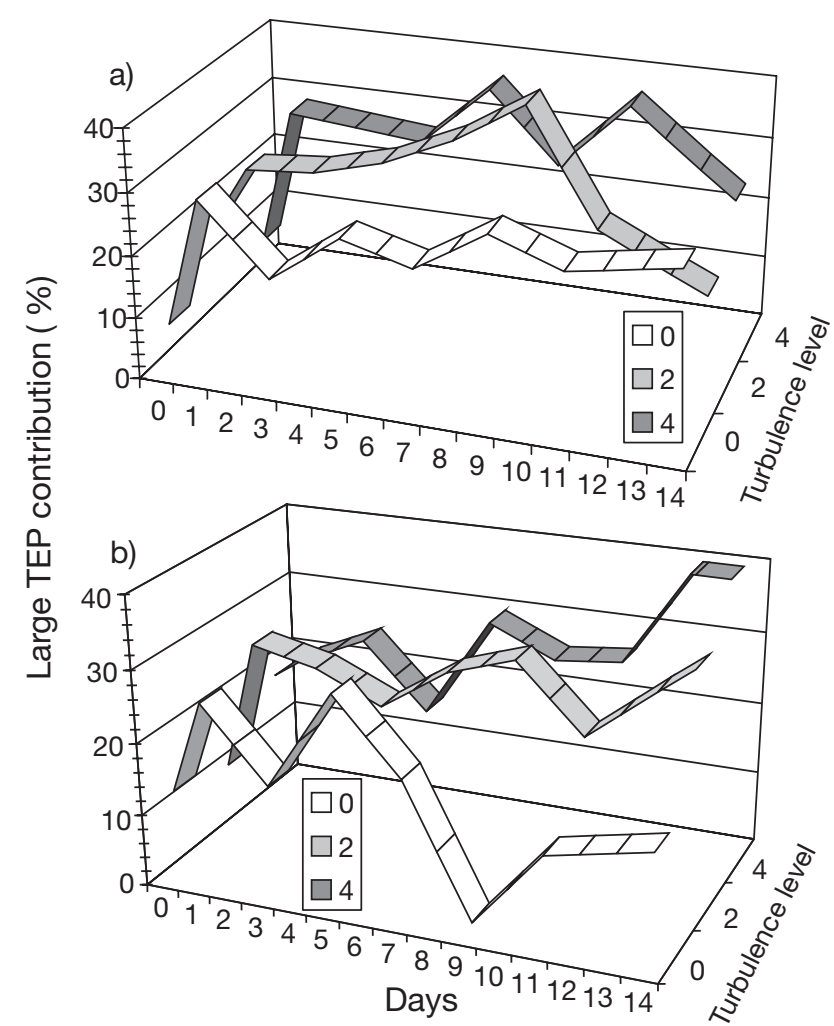

Fig. 4. Contribution of TEP $>40 \mu \mathrm{m}$ in still, intermediate and high turbulence intensity treatments $(0,2$ and 4 , respectively) in (a) T tanks and (b) in NT tanks*

were stronger (Fig. $6 ; y=0.02 x+7.22, \mathrm{R}^{2}=0.55 ; \mathrm{n}=24$, $\mathrm{p}<0.001)$. Regression analysis suggested that without TEP, the molar ratio of POM would be close to the Redfield ratio (6.4 in T tanks and 7.2 in NT tanks).

The ratio of TEP-C and C-phyto concentrations to daily cumulative PP (during the exponential phase) is an indicator of the portion of PP channeled into different C pools, assuming no carbon losses. The portion of PP converted into phytoplanktonic biomass was $13 \pm$ $2 \%$ in T tanks and $38 \pm 7 \%$ in NT tanks (Fig. 7). Moreover, the turbulence intensity increased the flux of $\mathrm{C}$ into the autotrophic compartment, particularly in NT tanks (from $30 \%$ in NT0 to $43 \%$ in NT4). The estimated PP fraction released to DOC and then chan-

*This figure was corrected after publication due to an error.

Panel (b) was replaced

Table 2. Enrichment factor (EF) of transparent exopolymeric particles (TEP) and chlorophyll a (conc. after resuspension experiment/conc. on Day 14) as a function of the level of turbulence intensity. $\mathrm{EF}=1$ means that material did not sink

\begin{tabular}{|c|c|c|c|c|c|c|}
\hline \multirow{2}{*}{$\begin{array}{l}\text { Turb. } \\
\text { level }\end{array}$} & \multirow{2}{*}{$\overline{\mathrm{TEP}}$} & \multicolumn{2}{|c|}{$-\mathrm{T}$ tanks } & \multirow{2}{*}{$\overline{\mathrm{TEP}}$} & \multicolumn{2}{|c|}{ NT tanks } \\
\hline & & Total chl a & Chl $a>10 \mu \mathrm{m}$ & & Total chl a & Chl $a>10 \mu \mathrm{m}$ \\
\hline 0 & 1 & 1.5 & 2.6 & 2.3 & 3.5 & 6.8 \\
\hline 2 & 1.3 & 1 & 1 & 4.4 & 1.1 & 1.1 \\
\hline 4 & 1 & 1 & 1 & 1 & 1 & 1.1 \\
\hline
\end{tabular}



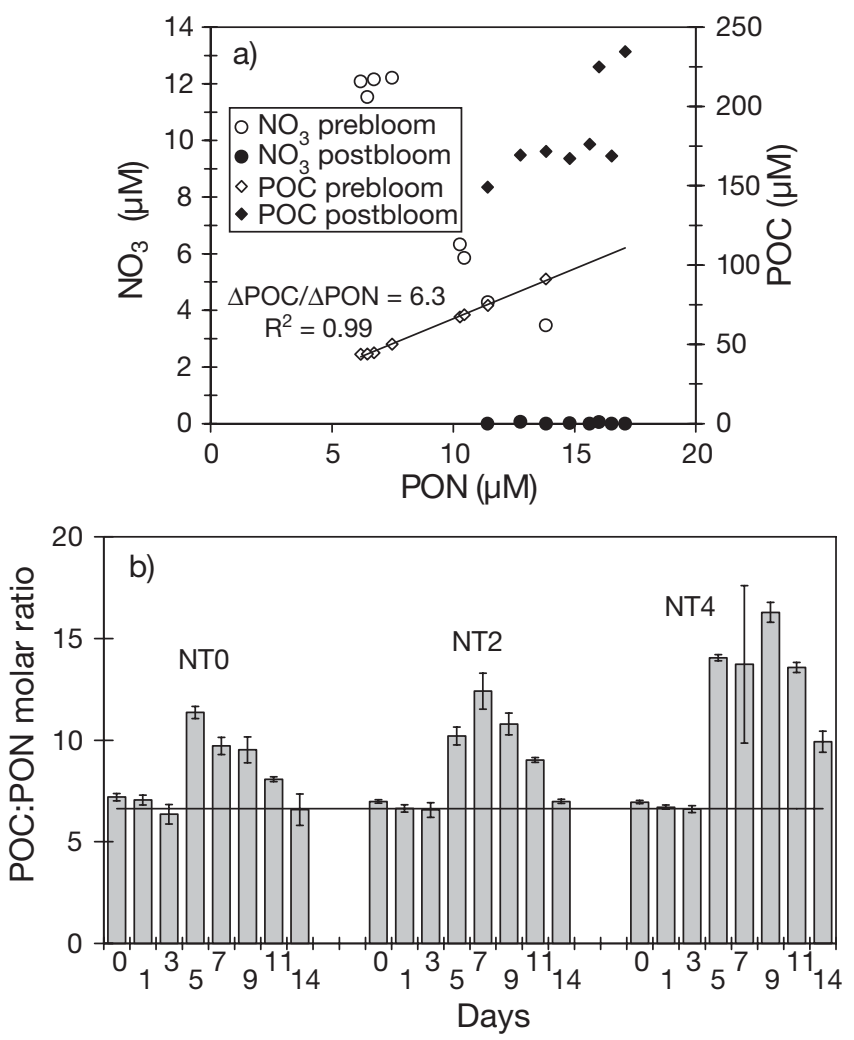

Fig. 5. (a) Temporal decoupling of carbon and nitrogen dynamics during the bloom in NT tanks. Tight co-variation of particulate organic carbon (POC) and nitrogen (PON) was observed until the bloom (Day 3), then a decoupling occurred (from Day 5) with a strong increase in POC, while PON concentrations increased more slowly. (b) Temporal variations of the POC:PON ratio in NT tanks. The horizontal line illustrates the Redfield ratio $(\mathrm{C}: \mathrm{N}=106: 16)$. Standard deviation bars correspond to different samples of the same mesocosm

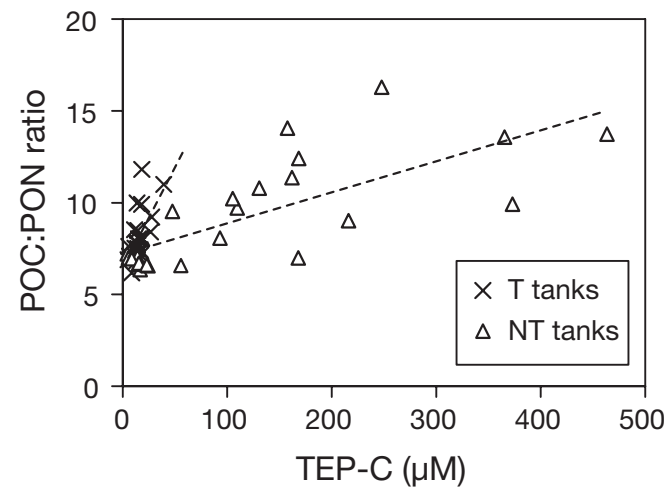

Fig. 6. Correlations between the $\mathrm{C}: \mathrm{N}$ ratio of particulate organic matter (POC:PON) and the TEP carbon (TEP-C) concentration in $\mathrm{T}$ tanks and NT tanks. Regression lines are significant: $y=0.11 x+6.44\left(\mathrm{~T}\right.$ tanks: $\mathrm{R}^{2}=0.38 ; \mathrm{n}=24 ; \mathrm{p}<$ $0.01)$ and $y=0.02 x+7.22\left(\mathrm{NT}\right.$ tanks: $\mathrm{R}^{2}=0.55 ; \mathrm{n}=24$; $\mathrm{p}<0.001)$

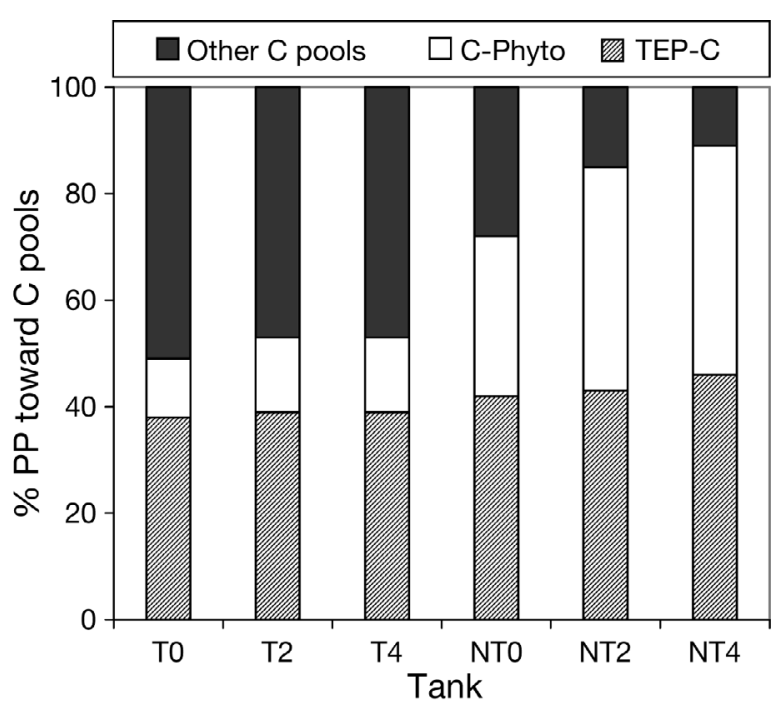

Fig. 7. Estimated fraction of the primary production (PP) channeled into the phytoplanktonic biomass (C-Phyto) and into the TEP pool (TEP-C) in the N and NT tanks. The remaining C pool represents the DOC, the loss by sedimentation, the respired $\mathrm{C}$ and the loss by grazing. Calculations were based on the ratio of C-Phyto (or TEP-C) to the daily cumulating PP, from Day 0 to the bloom. During this phase, we assumed that the entire PP fraction accumulated without sinking

neled into the TEP pool was relatively high $(39 \pm 1 \%$ in T tanks and $44 \pm 2 \%$ in NT tanks). While nutrient conditions seemed to have a slight effect on the PP fraction reaching the TEP pool, turbulent conditions had no effect (Fig. 7). The remaining carbon pool represents the $\mathrm{C}$ losses through, e.g., respiration, DOC release, grazing, or export by sedimentation.

\section{DISCUSSION}

\section{Factors influencing TEP production}

Diatoms are known to produce large amounts of TEP (Kiørboe \& Hansen 1993, Passow \& Alldredge 1994, Aluwihare \& Repeta 1999). In our experiment, the increase in the TEP concentration at the end of the diatom blooms (in the NT tanks) and the TEP accumulation 10 d later were likely due to Skeletonema costatum and Thalassiosira sp. S. costatum produced TEP during late bloom; during this period diatom concentration declined by $80 \%$. According to Engel (2000), the formation of aggregates at the end of diatom blooms may be due to enhanced coagulation efficiency in the presence of TEP. The aggregation rate is also controlled by the concentration of particles; as a consequence, TEP present in higher concentrations in NT tanks will have a tendency to stimulate more aggregation than those in $\mathrm{T}$ tanks. The significant difference 
between $\mathrm{T}$ and NT treatments could thus be attributed to particle concentrations.

While the production rate of TEP did not seem to be influenced by turbulence during the exponential phase (Fig. 2), nutrient conditions likely controlled TEP production by influencing exudation. However, higher chl a concentrations (Fig. 1) and PP (Fig. 7) were observed at higher turbulence intensity. This positive relationship between turbulent kinetic energy and the intensity of the phytoplankton bloom has already been demonstrated (Alcaraz et al. 2002, Arin et al. 2002) and confirms the role of exosomatic energy in the control of natural planktonic systems (Margalef 1978). Smallscale turbulence would favor large, non-mobile phytoplanktonic cells by maintaining them in the euphotic zone and by increasing nutrient fluxes around cells (Lazier \& Mann 1989, Arin et al. 2002). Thus, turbulence intensity has an indirect effect on TEP production by promoting the growth of diatom cells, which are the sources of TEP.

In the present study, TEP production increased when phytoplankton became nitrate limited. Skeletonema costatum produces large quantities of organic mucus under these conditions (Penna et al. 1999). When nitrates are depleted, a large proportion of the photosynthesized carbon is exuded and channeled into the TEP pool (Mari et al. 2001, Beauvais et al. 2003). We estimated that up to $44 \%$ of the PP could be released as DOC and reach the TEP pool (Fig. 7). Similarly, Alcaraz et al. (2002) showed that under turbulent conditions, between 30 and $50 \%$ of the net PP could be released as DOC. These results, and the elevated production of TEP to about $0.57 \mathrm{~d}^{-1}$ in NT tanks, confirmed that the TEP pool is a highly dynamic organic carbon pool.

Bacteria could also participate in TEP formation by producing polysaccharides as free exopolymers, capsules, or films (Decho 1990). Whereas in culture experiments bacteria can generate large amounts of TEP (Grossart 1999, Passow 2002a), in mesocosm experiments they contribute only 1 to $3 \%$ of TEP production (Stoderegger \& Herndl 1999). These authors also demonstrated that TEP production by bacteria is 5 -fold lower under turbulent conditions. Considering these results and the tight relationship between TEP and chl $a$ growth rates (Fig. 2), we hypothesize that the main source of TEP in our mesocosms was the exudation of precursors by phytoplankton rather than by bacteria.

\section{Carbon and nitrogen dynamics}

The decoupling of organic carbon and nitrogen after the bloom can be attributed, at least in part, to TEP formation. This decoupling was found in all turbulence tanks, but was stronger in NT4, where the TEP con- centration was higher. There was a strong co-variation of carbon and nitrogen, in accordance with the Redfield ratio before TEP formation. Then, TEP induced a modification of the stoichiometry of organic matter, with higher $\mathrm{C}: \mathrm{N}$ ratios. These experimental results thus corroborate previous observations on the in situ dynamics of TEP leading to the over-consumption of dissolved inorganic carbon in the NW Mediterranean Sea (Mari et al. 2001, Beauvais et al. 2003). Indeed, when nutrients limit biomass production, but not photosynthesis, polysaccharide exudation and subsequent TEP formation would result from a carbon surplus excreted by algal cells.

Engel et al. (2002), using mesocosm experiments, estimated that TEP production explained $40 \%$ of the decrease in dissolved inorganic carbon. In our experiment, we found that sedimentation of TEP was significant when turbulence was low (Table 2). As a considerable part of the DOC pool is transferred to the TEP pool, TEP could play a major role in the conversion of DOC to POC and the subsequent sedimentation of POC (Alldredge et al. 1995, Passow 2002b). It appears then that turbulence can modify $\mathrm{C}$ flux by altering the TEP pool in surface waters. At the end of the experiment, the C:N ratio of POM returned to values close to the Redfield ratio. This general decrease in the C:N ratio could be attributed to regulation processes mediated by bacterial activity. It has been shown that the ecto-enzymes released by bacteria that are attached to marine aggregates render the aggregates soluble (Kirchman et al. 1991, Smith et al. 1992). Indeed, at the end of the experiment, a large fraction of bacteria is attached to TEP (M. L. Pedrotti unpubl. data). Bacteria might degrade TEP by mineralization, regulating the $\mathrm{C}: \mathrm{N}$ ratio of total organic matter.

\section{Effect of turbulence on TEP aggregation and sedimentation}

The TEP size distribution was fitted by a power-law function, with a slope typical of fractal particles mainly controlled by coagulation process (Jiang \& Logan 1991, Alldredge et al. 1993, Li et al. 1998). Slopes of the TEP size distribution $(-2.5$ in $\mathrm{T}$ and -2.3 in NT) were in accordance with slopes of the particle size distribution (PSD) found when fluid shear, rather than Brownian motion or differential sedimentation, is the dominant collision mechanism (Li et al. 2004). This, thus, supports the idea that turbulence affects TEP coagulation. Interestingly, however, we did not find any significant effect of turbulence intensity on the TEP size spectrum for particles $<40 \mu \mathrm{m}$. These experimental results corroborate the numerical approach used by Li et al. (2004) to simulate the PSD in 
marine waters. They found that the PSD slope is mainly a function of the size range and fractal dimension of the particles concerned; environmental conditions do not significantly alter the general shape of the PSD curve for particles $<60 \mu \mathrm{m}$. However, in our mesocosm experiment, the size distribution of larger particles was altered by turbulence.

We found that the contribution of TEP $>40 \mu \mathrm{m}$ increased with intermediate and maximal turbulence intensity. Non-steady state conditions in natural waters could be the main reason for the deviation of the size distribution in the ocean. A change in the property of the particles, such as stickiness, would result in higher collision efficiency and will enhance particle flocculation, modifying the size spectrum toward larger sizes that can more readily be removed by sedimentation (Kiørboe \& Hansen 1993, Logan et al. 1995, Engel 2000, Li et al. 2004). Turbulence intensifies the probability of aggregate formation by increasing collision and coagulation rates (McCave 1984, Kiørboe 1997), which, in turn, may promote rapid settling of TEP depending on the level of turbulence.

Since TEP are the major agent for the aggregation of most natural phytoplankton blooms (Engel 2000, Passow et al. 2001), we suggest that, in situ, turbulence intensity similar to Level 2 (T2 and NT2) could enhance the vertical flux of TEP-phytoplankton aggregates by increasing the coagulation process. Inversely, stronger turbulence could affect the fate of the bloom by maintaining this pool in surface water, limiting carbon export and, thus, possibly accelerating the transfer of carbon from TEP to the microbial loop. This was suggested by the re-suspension assay.

With our set-up, we generated turbulence over the range of realistic levels found in the euphotic zone in the ocean, notably in coastal areas (Kiørboe \& Saiz 1995). Turbulence levels compiled in Mackenzie \& Legget (1993) ranged from $10^{-6}$ to $1 \mathrm{~cm}^{2} \mathrm{~s}^{-1}$. The latter value is an extreme situation of strong tidal current. It corresponds to a wind mixing value of $<25 \mathrm{~m} \mathrm{~s}^{-1}$ in the upper water layer, calculated with the formula provided by MacKenzie \& Legget (1993), which, according to J. E. Stiansen (pers. comm.), is not rare on the coast of Norway.

We found that the sedimentation of TEP was not always linked to that of phytoplankton. Passow et al. (2001) showed that only half of the TEP sinking flux in the Santa Barbara Channel could be explained by diatom vertical flux, suggesting that other factors influenced TEP sedimentation. Further studies will be necessary to assess the role of metazoans in TEP sedimentation.

This study showed that micro-scale turbulence has an effect on the TEP dynamics affecting carbon fluxes: (1) indirectly by enhancing TEP production by phyto- plankton and (2) directly by favoring TEP aggregation. Turbulence changes the DOM matrix by increasing the aggregation of organic matter, leading to a larger TEP pool. The persistence of this pool in surface waters or its sedimentation depends on the level of turbulence. The role of TEP as an organic substrate for bacteria and the influence of turbulence on changing the substrate's availability need to be further investigated in the future.

Acknowledgements. We thank A. Jacobsen for phytoplankton determinations and all the workshop participants for helpful discussions and for the excellent ambiance that prevailed at the Espeland Station. We also thank C. M. Duarte for useful comments and John Dolan for improving the English. The turbulent system was designed by Y. E. Stiansen and F. Peters. Access to installations was funded by the Large-Scale Facility of the University of Bergen and by the Improving Human Potential Programme from the EU through Contract No. HPRI-CT-1999-00056. This research was funded as part of the shared cost research project NTAP (Contract No. EVK3-CT-2000-00022) by the key action 'Sustainable Marine Ecosystems' of the EU RTD Programme 'Environment and Sustainable Development' and forms part of the ELOISE projects cluster.

\section{LITERATURE CITED}

Alcaraz M, Peters F, Arin L, Malits A (2002) Effects of turbulence conditions on the balance between production and respiration in marine planktonic community. Mar Ecol Prog Ser 242:63-71

Alldredge AL, Passow U, Logan BE (1993) The abundance and significance of a class of large, transparent organic particles in the ocean. Deep-Sea Res 40:1131-1140

Alldredge AL, Gotschalk C, Passow U, Riebesell U (1995) Mass aggregation of diatom blooms: insights from a mesocosm study. Deep-Sea Res 42:9-28

Aluwihare LI, Repeta DJ (1999) A comparison of the chemical characteristics of oceanic DOM and extracellular DOM produced by marine algae. Mar Ecol Prog Ser 186: 105-117

Arin L, Marrasé C, Maar M, Peters F, Sala MM, Alcaraz M (2002) Combined effects of nutrients and small-scale turbulence in a microcosm experiment. I. Dynamics and size distribution of osmotrophic plankton. Aquat Microb Ecol 29:51-61

Beauvais S, Pedrotti ML, Villa E, Lemée R (2003) Transparent exopolymer particle (TEP) dynamics in relation to trophic and hydrological conditions in the NW Mediterranean. Mar Ecol Prog Ser 262:97-109

Caparroy P, Pérez MT, Carlotti F (1998) Feeding behaviour of Centropages typicus in calm and turbulent conditions. Mar Ecol Prog Ser 168:109-118

Dam HG, Drapeau DT (1995) Coagulation efficiency, organicmatter glues, and the dynamics of particles during a phytoplankton bloom in a mesocosm study. Deep-Sea Res 42:111-123

Decho AW (1990) Microbial exopolymer secretions in ocean environments: their role(s) in food webs and marine processes. Oceanogr Mar Biol Annu Rev 28:73-153

Dolan JR, Sall N, Metcalfe A, Gasser B (2003) Effects of turbulence on the feeding and growth of a marine oligotrich ciliate. Aquat Microb Ecol 31:183-192 
Engel A (2000) The role of transparent exopolymer particles (TEP) in the increase in apparent particle stickiness during the decline of a diatom bloom. J Plankton Res 22:485-497

Engel A, Goldthwait S, Passow A, Alldredge A (2002) Temporal decoupling of carbon and nitrogen dynamics in a mesocosm diatom bloom. Limnol Oceanogr 47:753-761

Engel A, Thomas S, Riebesell U, Rochelle-Newall E, Zondervan I (2004) Polysaccharide aggregation as a potential sink of marine dissolved organic carbon. Nature 428: 929-932

Gargas E (1975) A manual for phytoplankton primary production studies in the Baltic. The Baltic Marine Biologists Publication No. 2, The Danish Agency of Environmental Protection, Hørsholm

Grossart HP (1999) Interactions between marine bacteria and axenic diatoms (Cylindrotheca fusiformis, Nitzscia laevis and Thalassiosira weissflogii) incubated under various conditions in the lab. Aquat Microb Ecol 19:1-11

Grossart HP, Simon M (1997) Formation of macroscopic organic aggregates (lake snow) in a large lake: the significance of transparent exopolymer particles, phytoplankton, and zooplankton. Limnol Oceanogr 42:1651-1659

Havskum H, Hansen PJ, Berdalet E (2005) Effect of turbulence on sedimentation and net population growth of the dinoflagellate Ceratium tripos and interactions with its predator, Fragilidium subglobosum. Limnol Oceanogr 50: 1543-1551

Jackson GA (1995) TEP and coagulation during a mesocosm experiment. Deep-Sea Res 42:215-222

Jiang Q, Logan BE (1991) Fractal dimensions of aggregates determined from steady-state size distributions. Environ Sci Technol 25:2031-2038

Kiørboe T (1997) Small-scale turbulence, marine snow formation, and planktivorous feeding. Sci Mar 61(Suppl 1): $141-158$

Kiørboe T, Hansen LS (1993) Phytoplankton aggregate formation: observations of patterns and mechanisms of cell sticking and the significance of exopolymeric material. J Plankton Res 15:993-1018

Kiørboe T, Saiz E (1995) Planktivorous feeding in calm and turbulent environments with emphasis on copepods. Mar Ecol Prog Ser 122:135-145

Kirchman D, Susuki Y, Garside C, Ducklow HW (1991) High turnover rate of dissolved organic carbon during a spring phytoplankton bloom. Nature 352:612-614

Koroleff F (1983) Determination of phosphorus. In: Grasshof K, Ehrhardt M, Kremling K (eds) Methods of seawater analysis. Verlag Chemie, Weinheim, p 125-139

Lazier JRN, Mann KH (1989) Turbulence and the diffusive layers around small organisms. Deep-Sea Res 36:1721-1733

Li X, Logan BE (1997) Collision frequencies of fractal aggregates with small particles by differential sedimentation. Environ Sci Technol 31:1229-1236

Li XW, Passow U, Logan BE (1998) Fractal dimension of small $(15-200 \mu \mathrm{m})$ particles in eastern Pacific coastal waters. Deep-Sea Res 45:115-131

Li X, Zhang J, Lee JH (2004) Modelling particle size distribution dynamics in marine waters. Water Res 38:1305-1317

Logan BE, Grossart HP, Simon M (1994) Direct observation of phytoplankton, TEP and aggregates on polycarbonate filters using brightfield microscopy. J Plankton Res 16: 1811-1815

Logan BE, Passow U, Alldredge AL, Grossar HP, Simon M (1995) Rapid formation and sedimentation of large aggregates is predictable from coagulation rates (half-lives) of transparent exopolymer particles (TEP). Deep-Sea Res 42: 203-214
Maar M, Arin L, Simo R, Sala MM, Peters F, Marrasé C (2002) Combined effects of nutrients and small-scale turbulence in a microcosm experiment. II. Dynamics of organic matter and phosphorous. Aquat Microb Ecol 29:63-72

MacKenzie BR, Legget WC (1993) Wind-based models for estimating the dissipation rates of turbulent energy in aquatic environments: empirical comparisons. Mar Ecol Prog Ser 94:207-216

Maltis A, Peters F, Bayer-Giraldi M, Marassé C, Zoppini A, Guadayol O, Alcaraz M (2004) Effects of small-scale turbulence on bacteria: a matter of size. Microb Ecol 48:287-299

Margalef R (1978) Life-forms of phytoplankton as survival alternatives in an unstable environment. Oceanol Acta 1: 493-509

Mari X (1999) Carbon content and C:N ratio of transparent exopolymeric particles (TEP) produced by bubbling exudates of diatoms. Mar Ecol Prog Ser 183:59-71

Mari X, Burd A (1998) Seasonal size spectra of transparent exopolymeric particles (TEP) in a coastal sea and comparison with those predicted using coagulation theory. Mar Ecol Prog Ser 163:63-76

Mari X, Kiørboe T (1996) Abundance, size distribution and bacterial colonization of transparent exopolymeric particles (TEP) during spring in the Kattegat. J Plankton Res 18:969-986

Mari X, Beauvais S, Lemée R, Pedrotti ML (2001) Non-Redfield C:N ratio of transparent exopolymeric particles in the northwestern Mediterranean Sea. Limnol Oceanogr 46: 1831-1836

McCave IN (1984) Size spectra and aggregation of suspended particles in the deep ocean. Deep-Sea Res 31:329-352

Myklestad S, Haug A (1972) Production of carbohydrates by the marine diatom Chaetoceros affinis var. Willei. I. Effect of the concentration of nutrients in the culture medium. J Exp Mar Biol Ecol 9:125-136

Nerheim S, Stiansen JE, Svendsen H (2002) Grid-generated turbulence in a mesocosm experiment. Hydrobiologia 484: 61-73

Parsons TR, Maita Y, Lalli CM (1984) A manual of chemical and biological methods for seawater analysis. Pergamon Press, Oxford

Passow U (2002a) Production of transparent exopolymeric particles (TEP) by phyto- and bacterioplankton. Mar Ecol Prog Ser 236:1-12

Passow U (2002b) Transparent exopolymer particles (TEP) in aquatic enviroments. Prog Oceanogr 55:287-333

Passow U, Alldredge AL (1994) Distribution, size and bacterial colonization of transparent exopolymer particles (TEP) in the ocean. Mar Ecol Prog Ser 113:185-198

Passow U, Alldredge AL (1995) Aggregation of a diatom bloom in a mesocosm: the role of transparent exopolymer particles (TEP). Deep-Sea Res 42:99-109

Passow U, Shipe RF, Murray A, Pak DK, Brzezinski MA, Alldredge A (2001) The origin of transparent exopolymeric particles (TEP) and their role in the sedimentation of particulate matter. Cont Shelf Res 21:327-346

Penna A, Berluti S, Penna N, Magnani M (1999) Influence of nutrient ratios on the in vitro extracellular polysaccharide production by marine diatoms from the Adriatic Sea. J Plankton Res 21:1681-1690

Peters F, Marrasé C (2000) Effects of turbulence on plankton: an overview of experimental evidence and some theoretical considerations. Mar Ecol Prog Ser 205:291-306

Peters F, Marrasé C, Gasol JM, Montserrat Sala M, Arin L (1998) Effects of turbulence on bacterial growth mediated through food web interactions. Mar Ecol Prog Ser 172: 293-303 
Prieto L, Ruiz J, Echevarria F, Garcia CM, Bartual A, Galvez JA, Corzo A, Macias D (2002) Scales and processes in the aggregation of diatom blooms: high time resolution and wide size range records in a mesocosm study. Deep-Sea Res 49:1233-1253

Simon M, Grossart HP, Schweitzer B, Ploug H (2002) Microbial ecology of organic aggregates in aquatic ecosystems. Aquat Microb Ecol 28:175-211

Simpson JH, Crawford WR, Rippeth TP, Campbell AR, Choak JVS (1996) Vertical structure of turbulent dissipation in shelf seas. J Phys Oceanogr 26(8):1580-1590

Smith DC, Simon M, Alldredge AL, Azam F (1992) Intense hydrolytic enzyme activity on marine aggregates and implications for rapid particle dissolution. Nature 359: $139-141$

Steeman-Nielsen E (1952) The use of radioactive carbon $\left({ }^{14} \mathrm{C}\right)$

Editorial responsibility: Otto Kinne (Editor-in-Chief),

Oldendorf/Luhe, Germany for measuring organic production in the sea. J Cons Int Explor Mer 18:117-140

Stiansen JE, Sundby S (2001) Improved methods for generating and estimating turbulence in tanks suitable for fish larvae experiments. Sci Mar 65:151-167

Stoderegger KE, Herndl GJ (1999) Production of exopolymer particles by marine bacterioplankton under contrasting turbulence conditions. Mar Ecol Prog Ser 189:9-16

Valderrama JC (1995) Methods of nutrient analysis. In: Hallagraeff GM, Anderson DM, Cembella AD (eds) Manual on harmful marine microalgae. IOC manuals and guides. UNESCO, Paris, p 251-268

Zhou J, Mopper K, Passow U (1998) The role of surface-active carbohydrates in the formation of transparent exopolymer particles by bubble adsorption of seawater. Limnol Oceanogr 43:1860-1871

Submitted: December 21, 2004; Accepted: March 23, 2006

Proofs received from author(s): September 22, 2006 